Economics Development Analysis Journal 7(3)(2018)

\title{
Determinan Kemiskinan di Provinsi Jawa Tengah Tahun 2011-2014
}

\author{
Emi Megawati ${ }^{1 \bowtie}$, Lesta Karolina Br Sebayang ${ }^{2}$
}

Jurusan Ekonomi Pembangunan, Fakultas Ekonomi, Universitas Negeri Semarang

\begin{tabular}{l} 
Info Artikel \\
\hline Sejarah Artikel: \\
Diterima April 2018 \\
Disetujui Juni 2018 \\
Dipublikasikan Agustus \\
2018
\end{tabular}

Keywords:

HDI, GDRP, FEM,

Poverty, Financing

Education, Central Java

Province

\begin{abstract}
Abstrak
Berdasarkan data dari BPS, kemiskinan di Provinsi Jawa Tengah pada tahun 2011-2014 masih berada di peringkat kedua setelah DI Yogyakarta di Pulau Jawa-Bali. Penelitian ini menggunakan data panel dengan pendekatan Fixed Effect Model (FEM) dengan metode Generalized Least Square (GLS). Sumber data yang diperoleh dari Badan Pusat Statistik (BPS) dan Direktorat Jendral Perimbangan Keuangan Indonesia. Hasil penelitian menunjukan bahwa variabel IPM berpengaruh negatif dan signifikan terhadap kemiskinan di Provinsi Jawa Tengah. Sedangkan variabel PDRB dan pembiayaan pendidikan berpengaruh tidak signifikan terhadap kemiskinan di Provinsi Jawa Tengah. Hasil uji secara bersama-sama menunjukan bahwa secara keseluruhan variabel bebas secara bersama-sama dapat menunjukan pengaruhnya terhadap kemiskinan. nilai dari Adjusted R2 sebesar 0,995 yang berarti 99,5 persen kemiskinan dapat dijelaskan oleh variabel bebas. Sedangkan sisanya 0,50 persen dijelaskan oleh variabel di luar model.
\end{abstract}

\begin{abstract}
Based on data from BPS, during years 2011-2014 Central Java Province are in number 2 after DI Yogyakanta in Java-Bali. This research use panel data with Fixed Effect Model (FEM) approach and by using Geberalized Square (GLS) method. The data source is secondary data are obtained from the Central Statistics Agency and the Directorate General of Financial Balance Indonesia. The result of this research show that HDIvariablegive the negative and significant influence to the poverty in Central Java province. GDRP and financingofeducation not significant influence to the poverty in Central Java province. Simultaneous test results showedthat, overall, the independent variable (HDI, GDRP and financing of education) together can show its effect on poverty. the value of Adjusted $R 2$ of 0,995, which means 99,5 percent of poverty can be explained by the independentvariable. While the remaining 0,50 percent is explained by variables outside the model.
\end{abstract}

\begin{tabular}{lr}
\hline Alamat korespondensi: & ISSN 2252-6965 \\
Ruang Jurnal Gedung L FE UNNES, Sekaran Gunungpati & \\
Semarang, 50229, Indonesia & \\
E-mail: mega.jeje25@gmail.com &
\end{tabular}




\section{PENDAHULUAN}

Perencanaan merupakan sebuah upaya untuk mengantisipasi ketidakseimbangan yang terjadi yang bersifat akumulatif. Artinya, perubahan yang terjadi pada sebuah keseimbangan awal dapat menyebabkan perubahan pada sistem sosial yang kemudian akan membawa sistem yang ada menjauhi keseimbangan semula. Perencanaan memiliki peran yang sangat penting dalam proses pembangunan.

Salah satu peran perencanaan adalah sebagai arahan bagi proses pembangunan untuk berjalan menuju tujuan yang ingin dicapai disamping sebagai tolok ukur keberhasilan proses pembangunan yA006Eg dilakukan. Sedangkan pembangunan sendiri dapat diartikan sebagai upaya yang dilakukan untuk meningkatkan pertumbuhan Produk Domestik Bruto (PDB) di tingkat nasional atau Produk Domestik Regional Bruto (PDRB) di tingkat daerah.

Kemiskinan merupakan salah satu penyakit suatu negara, sehingga harus disembuhkan atau paling tidak dikurangi. Permasalahan kemiskinan memang merupakan permasalahan yang kompleks dan bersifat multidimensional. Oleh karena itu, upaya pengentasan kemiskinan harus dilakukan secara komprehensif, mencakup berbagai aspek kehidupan masyarakat, dan dilaksanakan secara terpadu (Marmujiono, 2014:160).

Tabel 1. Presentase Penduduk Miskin di Pulau Jawa-Bali Tahun 2011-2014

\begin{tabular}{llllll}
\hline \multirow{2}{*}{ Provinsi } & \multicolumn{3}{l}{ Tingkat Kemiskinan (\%) } & & \\
& 2011 & 2012 & 2013 & 2014 & Rata-rata \\
\hline DKI Jakarta & 3,75 & 3,69 & 3,72 & 4,09 & 3,81 \\
Jawa Barat & 10,65 & 10,09 & 9,61 & 9,44 & 9,94 \\
Jawa Tengah & 15,76 & 15,34 & 14,44 & 14,46 & 15 \\
DI Yogyakarta & 16,08 & 16,05 & 15,03 & 15 & 15,54 \\
Jawa Timur & 14,23 & 13,4 & 12,73 & 12,28 & 13,16 \\
Baten & 6,32 & 5,85 & 5,35 & 5,51 & 5,75 \\
Bali & 4,2 & 4,18 & 3,95 & 4,53 & 4,21 \\
\hline
\end{tabular}

Sumber: Badan Pusat Statistik, data diolah

Berdasarkan Tabel 1.1 dengan angka ratarata tingkat kemiskinan di Provinsi Jawa Tengah 15 persen masih terbilang tinggi karena tergolong hard core ( $>10$ persen) yang mengindikasikan kebijakan pengentasan kemiskinan yang dijalankan pemerintah Provinsi masih belum berjalan dengan optimal.

Situasi perekonomian yang semakin membaik menyebabkan berkurangnya penduduk yang hidup dibawah garis kemiskinan. Hal ini ditunjukan dengan berkurangnya jumlah penduduk miskin dari tahun ke tahun. BPS (2015), pada tahun 2011 jumlah penduduk miskin sebesar 5,26 juta jiwa atau sekitar 15,76 persen. Kemudian tahun 2012 menurun menjadi 4,95 juta jiwa atau sekitar 15,34 persen. Pada tahun 2014 turun lagi menjadi 4,81 juta jiwa atau sekitar 14,46 persen dari total jumlah penduduk Provinsi Jawa Tengah.
Jumlah penduduk miskin merupakan salah satu tolok ukur keberhasilan kebijakan yang diambil pemerintah daerah untuk menyejahterakan masyarakatnya. Kesejahteraan masyarakat suatu negara atau daerah dapat dilihat dari pemerataan PDB di tingkat nasional atau PDRB di tingkat daerah.

Laju pertumbuhan PDRB Provinsi Jawa Tengah tahun 2014 mencapai 5,42 persen, lebih cepat dibandingkan tahun 2013 dengan laju pertumbuhan 5,14 persen yang mengalami penurunan dari tahun 2012 dari 5,34 persen menjadi 5,14 persen. Penurunan tersebut disebabkan kondisi perekonomian global yang belum mengalami perbaikan yang signifikan. Dari sisi sektoral, perlambatan terjadi pada sektor industri pengolahan, serta sektor perdagangan, hotel dan restoran. 
Emi Megawati \& Lesta Karolina Br Sebayang/ Economics Development Analysis Journal 7 (3) (2018)

Tabel 2. Produk Domestik Regional Bruto Atas Dasar Harga Konstan 2010 dan Laju Pertumbuhan Ekonomi Provinsi Jawa Tengah Tahun 2011-2014

\begin{tabular}{lll}
\hline Tahun & $\begin{array}{l}\text { PDRB ADHK 2010 } \\
\text { (Juta Rupiah) }\end{array}$ & $\begin{array}{l}\text { Laju Pertumbuhan } \\
\text { Ekonomi (\%) }\end{array}$ \\
\hline 2011 & $656.268 .129,91$ & 5,30 \\
2012 & $691.343 .115,96$ & 5,34 \\
2013 & $726.899 .706,38$ & 5,14 \\
2014 & $766.271 .771,27$ & 5,42 \\
\hline
\end{tabular}

Sumber: Badan Pusat Statistik, berbagai terbitan

Selain dilihat dari pertumbuhan ekonomi, kualitas sumber daya manusia juga dapat menjadi faktor penyebab terjadinya penduduk miskin. Kualitas sumber daya manusia dapat dilihat dari indeks kualitas hidup/indeks pembangunan manusia. Rendahnya Indeks Pembangunan Manusia (IPM) akan berakibat pada rendahnya produktivitas kerja dari penduduk. Produktivitas yang rendah berakibat pada rendahnya perolehan pendapatan. Sehingga dengan rendahnya pendapatan menyebabkan tingginya jumlah penduduk miskin.

Lanjouw dalam Saputra (2011:45) menyatakan pembangunan manusia di Indonesia adalah identik dengan pengurangan kemiskinan. Investasi di bidang pendidikan dan kesehatan akan lebih berarti bagi penduduk miskin dibandingkan penduduk tidak miskin, karena bagi penduduk miskin aset utama adalah tenaga kasar mereka. Adanya fasilitas pendidikan dan kesehatan murah akan sangat membantu untuk meningkatkan produktifitas, dan pada gilirannya meningkatkan pendapatan. Secara umum, pembangunan manusia Provinsi Jawa Tengah terus mengalami kemajuan selama periode 2011-2014. IPM di Provinsi Jawa Tengah meningkat dari 66,64 persen pada tahun 2011 menjadi 68,78 persen pada tahun 2014. Pada periode 2013-2014, IPM Provinsi Jawa Tengah meningkat sebesar 0,76 poin. Peningkatan pada periode tersebut lebih rendah apabila dibandingkan dengan periode 2012-2013, yang naik sebesar 0,81 poin. Meskipun selama periode 2011-2014 IPM Provinsi Jawa Tengah menunjukan kemajuan yang besar, status pembangunan manusia Provinsi Jawa Tengah masih stagnan. Hingga saat ini, pembangunan manusia Provinsi Jawa Tengah masih berstatus "sedang", dan masih sama sejak tahun 2010 .

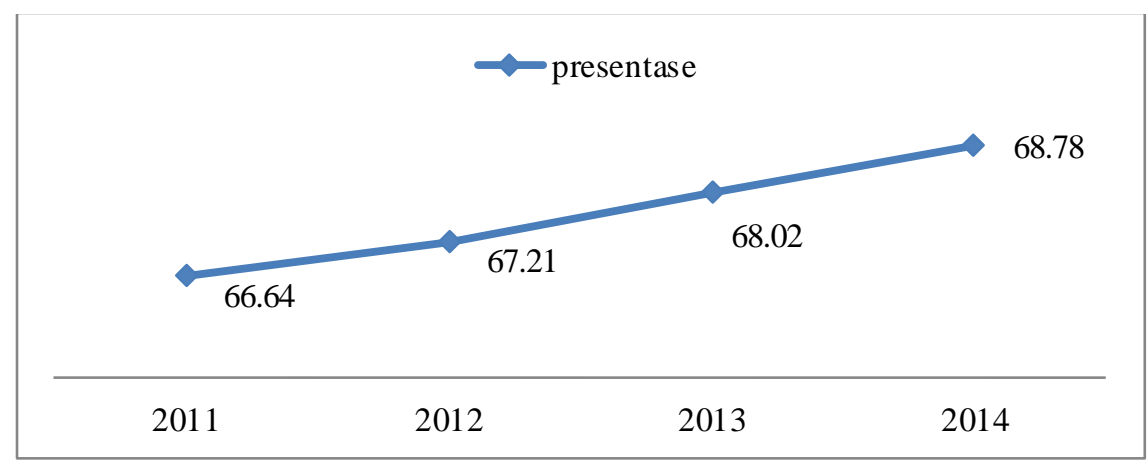

Gambar 1. Presentase Indeks Pembangunan Manusia Provinsi Jawa Tengah Tahun 20112014

Sumber: Badan Pusat Statistik, 2014, data diolah 
Faktor lain yang berpengaruh terhadap kemiskinan adalah belanja pemerintah di bidang pendidikan. Pengeluaran pemerintah di bidang pendidikan tertuang di dalam Undang-Undang Nomor 20 Tahun 2003 yang menyebutkan bahwa dana pendidikan selain gaji pendidik dan biaya pendidikan kedinasan dialokasikan minimal 20 persen dari Anggaran Pendapatan dan Belanja Nasional (APBN) dan Anggaran Pendapatan dan Belanja Daerah (APBD).

Biaya atau anggaran bidang pendidikan di provinsi Jawa Tengah paling tinggi ke-4 setelah Provinsi DKI Jakarta, Provinsi Jawa Barat, dan
Provinsi Jawa Timur. Selain itu anggaran bidang pendidikan Provinsi Jawa Tengah dari tahun 2011-2014 selalu mengalami peningkatan. Hal ini disebabkan karena PAD (Pendapatan Asli Daerah) di Provinsi Jawa Tengah juga mengalami peningkatan dari tahun 2011-2014. Namun anggaran tersebut masih tergolong rendah jika dibandingkan dengan Provinsi DKI Jakarta, Provinsi Jawa Barat, dan Provinsi Jawa Timur. Kemiskinan di Provinsi Jawa Tengah masih tergolong tinggi meskipun anggaran bidang pendidikan selalu mengalami peningkatan.

Tabel 3. Anggaran Bidang Pendidikan Pulau Jawa-Bali Tahun 2011-2014

\begin{tabular}{lllll}
\multicolumn{5}{c}{ (jutaan rupiah) } \\
\hline Provinsi & 2011 & 2012 & 2013 & 2014 \\
\hline DIY & 254,362 & 273,588 & 251,362 & 326,872 \\
Bali & 219,402 & 219,904 & 237,859 & - \\
Banten & - & 250,024 & 301,333 & 341,898 \\
Jawa Barat & 684,529 & 735,731 & 831,95 & 684,577 \\
Jawa Tengah & 307,026 & 301,254 & 318,511 & 324,253 \\
Jawa Timur & 384,641 & 448,573 & 514,846 & 531,299 \\
DKI Jakarta & 8115,163 & 10120,366 & 12815,351 & - \\
\hline
\end{tabular}

Sumber: Direktorat Jendral Perimbangan Keuangan, data diolah

\section{METODE PENELITIAN}

Jenis data yang digunakan adalah data sekunder terdiri dari data jumlah penduduk miskin, IPM, PDRB dan pengeluaran pemerintah bidang pendidikan. Penelitian ini menggunakan analisis panel data sebagai alat pengolahan data dengan bantuan Eviews-9. Gujarati (2012:237), menyatakan bahwa untuk menggambarkan data panel secara singkat, misalkan pada data cross section, nilai dari satu variabel atau lebih dikumpulkan untuk beberapa unit sampel pada suatu waktu. Dalam data panel, unit cross section yang sama disurvei dalam beberapa waktu.

Penelitian ini mengenai pengaruh variabel Indeks Pembangunan Manusia (IPM), Produk Domestik Regional Bruto (PDRB), dan pembiayaan pendidikan (PP) terhadap jumlah penduduk miskin (PM). Menggunakan pendekatan Fixed Effect Model (FEM) dengan metode Generalized Least Square (GLS).
Model fungsi yang digunakan untuk mengetahui kemiskinan di Provinsi Jawa Tengah yaitu:

PMit $=\beta 0+\beta 1$ IPMit $+\beta 2$ PDRBit $+\beta 3$ PPit +

$\mu$ it.

Dimana:

PM = Jumlah penduduk miskin kabupaten/kota di Jawa Tengah

IPM = Indeks pembangunan manusia kabupaten/kota di Jawa Tengah

PDRB = Jumlah PDRB kabupaten/kota di Jawa Tengah

PP $\quad=$ Pembiayaan pendidikan kabupaten/kota di Jawa Tengah

$\beta 0=$ Intersep

$\beta 1, \beta 2, \beta 3=$ Koefisien regresi variabel bebas

$\mu$ it $\quad=$ Komponen error di waktu t untuk unit cross section $\mathrm{i}$

i $\quad=1,2,3, \ldots, 35$ (data cross section kabupaten/kota di Jawa Tengah)

$\mathrm{t} \quad=1,2,3,4$ (data time series, tahun 20112014). 


\section{HASIL DAN PEMB AHASAN}

Berdasarkan hasil regresi pengaruh jumlah penduduk, IPM, PDRB, dan pembiayaan pendidikan (PP) terhadap kemiskinan di Provinsi Jawa Tengah tahun 2011-2014, dengan menggunakan metode FEM, diperoleh nilai koefisien regresi untuk setiap variabel dalam penelitian dengan persamaan sebagai berikut:

$$
\begin{aligned}
\text { PMit }= & \beta 0-\beta 1 \text { IPMit }-\beta 2 \text { PDRBit }+\beta 3 \text { PPit }+ \\
& \mu \text { it }(\ldots \ldots \ldots \ldots \ldots \ldots \ldots \ldots \ldots \ldots \ldots \ldots \ldots \ldots \ldots \ldots \ldots \ldots \ldots \ldots \ldots \ldots \ldots \ldots \ldots \ldots \ldots \ldots \ldots \ldots \\
\text { PMit }= & 743521,9-8757,928 \text { IPMit }-0,390412 \\
& \text { PDRBit }+0,0000000390 \text { PPit }+\mu \text { it }(\ldots .2)
\end{aligned}
$$

Berdasarkan hasil di atas dapat diketahui nilai konstanta sebesar 743521,9. Apabila variabel independen dianggap konstan/nol, maka besarnya nilai penduduk miskin sebesar 743521,9 dengan asumsi ceteris paribus. Sedangkan nilai IPM sebesar $-8757,928$. Hal ini menunjukan bahwa apabila IPM mengalami peningkatan sebesar 1 satuan maka akan dapat menurunkan jumlah pendudk miskin sebesar 8.757 jiwa ceteris paribus. Nilai PDRB sebesar 0,390412 yang berarti apabila PDRB mengalami peningkatan sebesar $1 \%$ maka jumlah penduduk miskin akan mengalami penurunan sebesar $39,04 \%$ dengan asumsi ceteris paribu. Nilai koefisien untuk pembiayaan pendidikan sebesar 0,0000000390 yang berarti bahwa apabila pembiayaan pendidikan mengalami peningkatan sebesar $1 \%$ maka jumlah penduduk miskin akan meningkat sebesar 0,0000390\% dengan asumsi ceteris paribus.

Model ekonometrika dikatakan baik apabila sudah memenuhi kriteria ekonometrika. Sedangkan kriteria ekonometrika adalah model yang digunakan harus terbebas dari gejala ekonometrika yaitu harus sesuai dengan asumsi klasik. Dan kesesuaian model dengan yang kriteria statistik dilihat dari hasil uji koefisien determinasi (R2), uji statistik F, dan uji statistik t. Sebelum melakukan uji statistika untuk mengetahui seberapa besar pengaruh variabel independen terhadap variabel dependen, maka terlebih dahulu melakukan uji asumsi klasik supaya data dalam penelitian ini valid dan terbebas dari masalah ekonometrika. Hasil dari
Asumsi klasik yang didapat adalah sebagai berikut:

\section{Uji Normalitas}

Berdasarkan perhitungan regresi menunjukkan bahwa nilai probabilitas JarqueBere sebesar 0,062019 sedangkan taraf nyata yang digunakan dalam penelitian ini yaitu $(\alpha=$ $5 \%$ ), sehingga diperoleh nilai Probabilitas Jarque-Bere sebesar 0,062019 $(6,20)>\alpha=5 \%$ $(0,05)$, maka dapat disimpulkan bahwa data yang digunakan dalam penelitian ini berdistribusi secara normal.

\section{Uji Autokorelasi}

Menurut Gujarati (2012:370) metode General Least Square (GLS) dapat menekan autokorelasi yang biasanya timbul dalam rumus OLS sebagai akibat kesalahan estimasi (underestimate) varians sehingga dengan metode GLS masalah dalam autokorelasi dapat diatasi. Estimasi data panel yang menggunakan fixed effect baik bersifat LSDV maupun GLS dapat mengabaikan terjadinya autokorelasi sehingga dengan menggunakan metode ini masalah autokorelasi sudah dapat teratasi.

\section{Uji Multikolinearitas}

Berdasarkan hasil perhitungan regresi dapat diketahui bahwa nilai R2 majemuk > R2 parsial $(0,996332>0,428017 ; 0,533035$; 0,109623). Berdasarkan hasil regresi tersebut, maka dapat disimpulkan bahwa model regresi yang digunakan dalam penelitian ini terbebas dari masalah multikolinearitas.

\section{Uji Heteroskedastisitas}

Berdasarkan hasil perhitungan regresi menunjukkan bahwa model regresi memiliki pvalue $\mathrm{Obs}^{*} \mathrm{R}$-square sebesar 46,37483 yang nilainya lebih besar dari taraf nyata yaitu sebesar $5 \%=0,05$. Oleh karena itu dapat disimpulkan bahwa pada model regresi bebas dari masalah heteroskedastisitas.

Penelitian ini model regresi sudah terbebas dari masalah ekonometrika. Dalam hal ini untuk mengetahui faktor-faktor yang menyebabkan investasi pada sekotr pertanian rendah melalui 
pengujian secara statistik. Pengujian secara statistik dalam hal ini berupa Uji koefisien determinasi, Uji F statistik, dan Uji t statistik.

\section{Uji F Statistik}

Berdasarkan hasil regresi yang diperoleh yaitu nilai F-hitung $=748,8704>$ F-tabel $=2,67$, maka keputusannya adalah Ho ditolak dan $\mathrm{Ha}$ diterima. Sehingga hasil uji F menyatakan bahwa variabel independen yaitu IPM, PDRB dan PP (pembiayaan pendidikan) secara bersama-sama berpengaruh secara nyata terhadap variabel dependen yaitu jumlah penduduk miskin di Provinsi Jawa Tengah.

\section{Uji t-Statistik}

Hasil Uji t-statistik pada Pengaruh IPM, PDRB dan PP Terhadap Kemiskinan di Kabupaten/Kota Provinsi Jawa Tengah

Berdasarkan Tabel 4 dapat diketahui bahwa tidak semua variabel bebas berpengaruh signifikan dalam model, dimana ada variabel bebas yang memiliki nilai probabilitas dari tstatistik yang lebih besar dari taraf nyata yang digunakan $(\alpha=0,5 \%)$. Adapun variabel bebas yang berpengaruh secara signifikan yaitu hanya IPM. Sedangkan PDRB dan PP tidak berpengaruh secara signifikan.

Tabel 4. Hasil Uji t-statistik pada Pengaruh IPM, PDRB dan PP Terhadap Kemiskinan di Kabupaten/Kota Provinsi Jawa Tengah

\begin{tabular}{lllll}
\hline Variabel & t-statistik & Probabilitas & t-tabel & Kesimpulan \\
\hline IPM & $-11,8787$ & 0,0000 & 1,978 & Signifikan pada $\alpha=5 \%$ \\
PDRB & $-0,9954$ & 0,3219 & 1,978 & Tidak signifikan pada $\alpha=5 \%$ \\
PP & 1,2451 & 0,2159 & 1,978 & Tidak Signifikan pada $\alpha=5 \%$ \\
\hline
\end{tabular}

Sumber: Data sekunder IPM, PDRB dan PP tahun 2011-2014, data diolah

\section{Uji Koefisien Determinasi (Adjusted R2)}

Koefisien determinasi ini menunjukkan tingkat atau derajat keakuratan hubungan antara variabel independen terhadap variabel dependen. Berdasarkan hasil regresi menunjukkan bahwa Adjusted R-square atau nilai dari R2 adalah 0,9949, yang berarti bahwa jumlah penduduk miskin dapat dijelaskan oleh variasi model dari IPM, PDRB dan PP sebesar 99,50\% dan sisanya sebesar $0,50 \%$ dijelaskan oleh variabel-variabel lain di luar model atau variabel-variabel lain yang tidak ada dalam penelitian ini

\section{Interpretasi Hasil dan Pembahasan IPM dan Kemiskinan}

Berdasarkan hasil estimasi menunjukkan bahwa nilai koefisien pada variabel IPM yaitu sebesar -8.757,928. Jika IPM mengalami kenaikan sebesar satu satuan maka jumlah penduduk miskin akan mengalami penurunan sebesar 8.757 jiwa. Menurut Lanjouw dalam Saputra (2015:45) menyatakan pembangunan manusia adalah identik dengan pengurangan kemiskinan. Investasi di bidang pendidikan dan kesehatan akan lebih berarti bagi penduduk miskin dibandingkan penduduk yang tidak miskin. Menurunnya angka kemiskinan saat IPM meningkat merupakan indikasi bahwa tingginya kualitas sumber daya manusia yang akan berakibat pada meningkatnya produktifitas kerja penduduk yang akan menyebabkan masyarakat mampu memenuhi kebutuhan hidupnya serta dapat menurunkan angka kemiskinan.

IPM memuat tiga komponen penting dalam pembangunan yaitu terkait dengan aspek pemenuhan kebutuhan akan hidup panjang umur dan hidup sehat, untuk mendapatkan pengetahuan dan mempunyai akses kepada sumber daya yang bisa memenuhi standar hidup. Artinya, tiga komponen penting dalam pembangunan manusia tersebut sangat berpengaruh terhadap kemiskinan (Napitupulu dalam Cholil, 2014:7). 


\section{PDRB dan Kemiskinan}

Berdasarkan hasil estimasi variabel PDRB menunjukan tanda negatif dan tidak signifikan terhadap kemiskinan. Nilai koefisien PDRB menunjukkan sebesar -0,390412. Jika PDRB mengalami kenaikan sebesar satu persen maka jumlah penduduk miskin akan turun sebesar 3,90412 persen. Menurut Siregar dalam Wibisono (2015:25) menyatakan bahwa pertumbuhan ekonomi merupakan syarat keharusan bagi pengurangan kemiskinan. Selain itu, syarat kecukupan adalah bahwa pertumbuhan tersebut efektif dalam mengurangi kemiskinan. Artinya, pertumbuhan itu hendaklah menyebar di setiap golongan pendapatan, termasuk di golongan penduduk miskin.

Penelitian yang dilakukan oleh Wibowo (2014), juga menyatakan bahwa pertumbuhan ekonomi berpengaruh negatif terhadap kemiskinan. Dengan naiknya pertumbuhan ekonomi dapat disimpulkan bahwa pertambahan pendapatan masyarakat juga meningkat. Apabila pendapatan masyarakat bertambah maka dapat diperkirakan masyarakat akan terbebas dari kemiskinan. Sehingga ketika pertumbuhan ekonomi naik maka kemiskinan akan turun.

\section{Pembiayaan Pendidikan dan Kemiskinan}

Berdasarkan hasil regresi nilai koefisien pada variabel PP (pembiayaan pendidikan) menunjukkan hasil positif yaitu sebesar 3,90E-09 (0,0000000390). Maka variabel pembiayaan pendidikan berpengaruh positif terhadap jumlah penduduk miskin. Artinya apabila pembiayaan pendidikan naik sebesar satu persen maka jumlah penduduk miskin akan mengalami peningkatan sebesar 0,000390 persen. Hal ini menunjukkan bahwa pembiayaan pendidikan meningkat tetapi tidak diikuti dengan penurunan jumlah penduduk miskin.

Pengeluaran pemerintah di bidang pendidikan tertuang di dalam UU Nomor 20 Tahun 2003 yang menyebutkan bahwa dana pendidikan selain gaji pendidik dan biaya pendidikan kedinasan dialokasikan minimal 20 persen dari APBD dan APBN. Tetapi pada kenyataannya dana tersebut habis untuk gaji pendidik bahkan alokasi untuk pendidikan sendiri belum mencapai 20 persen.

Penelitian yang dilakukan oleh Nurkolis (2011:8) bahwa Kabupaten Wonosobo dan Kabupaten Purworejo yang merupakan sampel dari penelitian menyatakan anggaran pendidikan termasuk gaji pendidik masing-masing mencapai 40-46 persen dan 46-55 persen dari realisasi belanja APBD tahun 2008-2011. Namun jika tidak termasuk gaji pendidik dan tenaga kependidikan di Kabupaten Wonosobo hanya berkisar 3-9 persen, sedangkan di Kabupaten Purworejo berkisar antara 5-9 persen.

Menurut Simmons yang dikutip dari Todaro dalam Wijayanto (2010:43), menyatakan bahwa pendidikan di banyak negara merupakan cara untuk menyelamatkan diri dari kemiskinan. Dimana digambarkan dengan sorang miskin yang mengharapkan pekerjaan yang baik serta penghasilan yang tinggi maka harus mempunyai tingkat pendidikan yang tinggi. Besaran dari pengeluaran ditetapkan oleh pemerintah dan pada akhirnya dapat mempengaruhi angka kemiskinan.

\section{SIMPULAN}

Berdasarkan hasil penelitian dan pengujian dapat ditarik kesimpulan bahwa variabel IPM memiliki pengaruh negatif dan signifikan terhadap kemiskinan di kabupaten/kota Provinsi Jawa Tengah. Variabel PDRB memiliki pengaruh negatif dan tidak signifikan terhadap kemiskinan di kabupaten/kota Provinsi Jawa Tengah. Sedangkan variabel pembiayaan pendidikan memiliki pengaruh positif dan tidak signifikan terhadap kemiskinan. Secara bersama-sama variabel IPM, PDRB dan pembiayaan pendidikan mampu memberikan penjelasan terhadap kemiskinan di kabupaten/kota Provinsi Jawa Tengah dengan koefisien sebesar 99,5\% dan sisanya sebesar $0,50 \%$ dijelaskan oleh variabel diluar model.

Pemerintah Provinsi Jawa Tengah per; $u$ meningkatkan lagi pelayanan di sektor pendidikan secara gratis bagi masyarakat miskin. Mempertajam program pembebasan biaya 
pendidikan khususnya untuk penduduk miskin dan perluasan akses pendidikan bagi semua. Pemerintah diharapkan tidak hanya terfokus pada pertumbuhan PDRB saja, tetapi pemerataannya juga harus lebih diperhatikan..

\section{DAFTAR PUSTAKA}

Adhi Saputra, Whisnu. 2011. "Analisis Pengaruh Jumlah Penduduk, PDRB, IPM, Pengangguran Terhadap Tingkat Kemiskinan di Kabupaten/Kota Jawa Tengah". Skripsi. Semarang. Fakultas Ekonomika dan Bisnis. Universitas Diponegoro.

Adi Wibowo, Dian. "Pengaruh Pembiayaan Pendidikan, Tingkat Pendidikan, Pertumbuhan Ekonomi dan Kemiskinan di Jawa Tengah". Jurnal Economic. Volume 10, Nomor 2, Oktober 2014.

Gujarati, D.N. dan D.C. Porter. 2012. Dasar-Dasar Ekonometrsika, Edisi 5 Buku 2. Jakarta: Salemba Empat.

Marmujiono, Slamet Priyo. 2014. "Analisis FaktorFaktor yang Mempengaruhi Tingkat Kemiskinan dan Strategi Pengentasan Kemiskinan di Kabupaten Brebes Tahun
2009-2011”. Economics Development Analysis Journal. 3 (1) (2014).

Mufid Cholil, Fathul. 2014. "Analisis Pengaruh Pengangguran, PDRB (Produk Domestik Regional Bruto) dan IPM (Indeks Pembangunan Manusia Terhadap Jumlah Penduduk Miskin (Studi Kasus 33 Provinsi Di Indonesia).

Skripsi. Malang. Fakultas Ekonomika dan Bisnis. Universitas Brawijaya.

Nurkolis. 2011. Belanja Pendidikan Tersedot Untuk Belanja Pegawai. IKIP PGRI. Semarang. Hal 1-16.

Undang-Undang Nomor 20 Tahun 2003 tentang Pengeluaran Pemerintah di Bidang Pendidikan.

Dwi Wijayanto, Ravi. 2010. "Analisis Pengearuh PDRB, Pendidikan dan Pengangguran

Terhadap Kemsikinan di Kabupaten/Kota Jawa Tengah Tahun 2005-2008". Skripsi. Semarang. Fakultas Ekonomika dan Bisnis. Universitas Diponegoro.

Yudi Wibisono, Radityo. 2015. "Analisis Pengaruh PDRB, Pengangguran dan Pendidikan Terhadap Kemiskinan di Jawa Tengah Tahun 2008-2013". Skripsi. Semarang. Fakultas Ekonomika dan Bisnis. Universitas Diponegoro. 